\title{
„DZIENNIK ZDROWIA DLA WSZYSTKICH STANÓW" FRANCISZKA LEOPOLDA LAFONTAINE'A A STAN WIEDZY MEDYCZNEJ W POCZĄTKACH WIEKU XIX. WYBRANE CHOROBY
}

\begin{abstract}
Streszczenie. Kwestia chorób i prób ich leczenia trapiła ludzkość od zarania dziejów. Jednakże wraz z upływem czasu stan wiedzy medycznej rósł, a w renesansie nastąpiło prawdziwe odżycie nauk o człowieku, co zaowocowało dziełami takich ludzi jak Wesaliusz, William Harvey czy Giambattista Morgagni, a w Rzeczypospolitej Wojciech Oczko czy też Joachim Delhafius. Symbolicznym dziełem, które wprowadza medycynę nie tylko w XIX w., ale też na głęboką prowincję jest Dziennik Zdrowia dla Wszystkich Stanów Franciszka Leopolda Lafontaine’a. Analiza trzech typów schorzeń: gruźlicy, kołtuna i spraw związanych z zębami w odniesieniu do innych badaczy pozwala porównać stan wiedzy medycznej nie tylko z tym, co występowało wcześniej, ale również z tym jak na wspomniane choroby patrzono później.
\end{abstract}

Słowa kluczowe: choroby, gruźlica, kołtun, zęby, zdrowie.

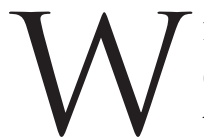

iek XIX stanowi przełom cywilizacyjny $\mathrm{w}$ batalii z wszelkimi chorobami, z którymi ludzkość dotychczas walczyła mało skutecznie lub też im całkowicie ulegała. Europa, w owym czasie najbardziej rozwijająca się część globu, stała się przodowniczką w poszukiwaniu panaceum albo chociaż jego namiastki, aby zabezpieczyć ludzi przed różnego rodzaju dolegliwościami, które ich z różnym nasileniem trapiły. Ospa, dżuma, cholera, tyfus, gruźlica zwana suchotami - to tylko niektóre ze schorzeń, wobec których świat stał bezradnie. Dziewiętnaste stulecie do 
stosunku lekarz-pacjent dodaje nową relację a mianowicie lekarz-społeczeństwo ${ }^{1}$, która od tej pory będzie pewnego rodzaju oczywistym standardem.

W przypadku podkreślenia tej drugiej współzależności, w historiografii wciąż zbyt cicho wybrzmiewa nazwisko Franciszka Leopolda Lafontaine'a (1756-1812). Urodzony w Biber w Wirtembergii, w wieku 18 lat rozpoczął studia medyczne w Strasburgu, a następnie kształcił się na praktyce w Wiedniu u Maksymiliana Stolla ${ }^{2}$. Od 1782 r. osiadł w Krakowie, jeszcze polskim, gdzie prowadził prywatny gabinet; działał również jako lekarz zdrojowy w dobrach księżnej marszałkowej Izabelli z Czartoryskich Lubomirskiej (w Krzeszowicach pod Krakowem). Od 1787 r. służył w Warszawie jako nadworny chirurg przy JKM Stanisławie Auguście Poniatowskim. Ożenił się z młodszą od niego o 12 lat Teresą z Kornelich (1768-1827). Po utworzeniu Księstwa Warszawskiego na mocy traktatu tylżyckiego w 1807 r. został mianowany głównym chirurgiem wojsk polskich; w 1809 r. nadano mu order Virtuti Militari, a w $1811 \mathrm{r}$. Legię Honorową. Brał udział w wyprawie na Moskwę. Zmarł 12 grudnia 1812 r. jako jeniec w Mohylewie podczas odwrotu wojsk napoleońskich³ .

Zanim pozwolę sobie przejść do bezpośredniego tematu pracy, uważam, że nieodzownym jej elementem, będzie opisanie, krótkie, aczkolwiek treściwe ówczesnego stanu medycyny oraz tego, co się przyczyniło do jej ukształtowania aż po początek wieku XIX ${ }^{4}$.

Podstawowym podręcznikiem dla studentów medycyny pozostawało szesnastowieczne dzieło Wesaliusza (1514-1564) De humani corporis fabrica libri septem z 1543 r. Zasadniczą rolę pełniły też badania anatomiczne Paracelsusa (1493/1494-1541). Wraz z upływem czasu następowało coraz to bardziej szczegółowe poznawanie ciała ludzkiego, wynikiem czego była publikacja spektakularnej pracy, która obowiązuje do dziś, a mianowicie Exercitatio anatomica de motu cordis et sangunis in animalibus Williama Harveya (1578-1657) z 1628 r., w której autor opisuje istotę oraz działanie małego i dużego krwioobiegu. Nie można też zapomnieć o dziele fizjologa Albrechta von Hallera (1708-1777) z lat 1757-1766 Elementa physiologiae

${ }^{1}$ J. Jeszke, Myśl europejska w medycynie polskiej w XIX w. w badaniach polskich historyków medycyny, „Medycyna nowożytna” 1996, nr 3/1-2, s. 75.

2 Maksymilian Stoll (1742-1787) - jeden z najwybitniejszych przedstawicieli Pierwszej Szkoły Wiedeńskiej, odważny eksperymentator w dziedzinie medycyny, propagator uzupełniania historii choroby w celu ułatwienia diagnostyki.

3 T. Ostrowska, Franciszek Leopold Lafontaine, [w:] Polski Słownik Biograficzny, t. XVI, Wrocław-Warszawa-Kraków 1971, s. 408-409.

${ }^{4}$ W tym miejscu zdecydowanie godną zauważenia pracą jest książka dr. Jakuba Węglorza o nowożytnej medycynie w Rzeczypospolitej. Zob. J. Węglorz, Zdrowie, choroba i lecznictwo w społeczeństwie Rzeczypospolitej XVI-XVIII wieku, Toruń 2015. 
corporis humani, które jest kompendium wiedzy anatomiczno-fizjologicznym dalece większym niż dzieło Wesaliusza, lecz równie ważnym ${ }^{5}$. Wraz z rozwojem sekcji zwłok zaczęto też skupiać się na badaniu przyczyn chorób oraz na zgłębianiu nauki o procesach chorobowych czyli patologii. Jej protoplastą był Giambattista Morgagni (1692-1771) - autor De sedibus et causis morborum per anatomen indagatis ${ }^{6}$.

Wynalazkiem przełomowym dla historii medycyny stał się opracowany w XVI w. mikroskop, ulepszony przez Antoniego van Leeuwenhoeka (16321723) oraz Roberta Hooke'a (1635-1703). Obaj byli członkami The Royal Society i obaj w latach 1665-1678 odkryli istnienie mikroorganizmów przy pomocy wynalezionych przez siebie urządzeń 7 . Podążali różnymi drogami, lecz jedno było pewne - ich odkrycia okazały się kamieniem milowym i początkiem takich nauk jak mikrobiologia czy cytologia.

A w jakim położeniu znajdowała się w owym czasie medycyna w Rzeczypospolitej? Należy pamiętać, że najstarszą uczelnią kształcącą lekarzy było Studium Generale Cracoviense, czyli Uniwersytet Jagielloński założony w 1364 r. z Wydziałem Lekarskim, który został zreformowany przez Hugona Kołłątaja w XVIII w. We Lwowie od 1661 r. zarządzeniem ówczesnego króla Jana II Kazimierza Wazy tamtejsze kolegium jezuickie zyskało miano uniwersytetu, a jednym z jego wydziałów stał się wydział lekarski. Obok uczelni krakowskiej i lwowskiej w Grodnie od 1776 r. działała uczelnia medyczna, która jednak została włączona do utworzonej w 1781 r. Szkoły Głównej Wileńskiej. W stolicy Litwy badania prowadził wybitny lekarz, chemik i filozof Jędrzej Śniadecki (1768-1838), brat Jana ${ }^{8}$.

Jeśli chodzi o nazwiska praktykujących i czynnie prowadzących badania lekarzy należy zacząć od poznaniaka Józefa Strusia (1510-1568), który wsławił się badaniami na temat tętna ${ }^{9}$, a w dziedzinie wenerologii i propagowania zdrowego trybu życia dał się zauważyć Wojciech Oczko (1537-1599), który napisał m.in. dzieło Cieplice sławiące balneologię i wody mineralne Iwonicza ${ }^{10}$. Niewybaczalne byłoby pominąć tutaj szamotulanina Jana Jonstona (1603-1675), którego dwunastotomowe dzieło Idea universae

${ }^{5}$ Z. Domosławski, Wprowadzenie do medycyny, Jelenia Góra 2007, s. 43.

6 Tamże, s. 46.

${ }^{7}$ H. Gest, The discovery of microorganisms by Robert Hooke and Antoni van Leeuwenhoek, fellows of the Royal Society, „Notes and Records of the Royal Society of London” 2004, nr 58 (2), s. 187.

${ }^{8}$ Z. Domosławski, dz. cyt., s. 62.

9 A. Grzybowski, J. Sak, Józef Struś (1510-1568) jako prekursor współczesnej wiedzy o układzie krążenia w 500. rocznicę jego urodzin, „Archiwum Historii i Filozofii Medycyny” 2011, vol. 74, s. 37-39.

10 M. Markiewicz, Historia Polski 1492-1795, Kraków 2011, s. 254. 
medicinae practicae stanowiło przez prawie 150 lat podstawową encyklopedię lekarską ${ }^{11}$. Gdańszczanin Joachim Delhafius (1570-1630) jako pierwszy w północnej Europie dokonał publicznej sekcji zwłok noworodka ${ }^{12}$. Warto też przypomnieć postać Johanna Adama Kulmusa (1689-1745), który urodził się we Wrocławiu, lecz większość życia spędził w kosmopolitycznym Gdańsku, gdzie stworzył Tabulae anatomicae (oryg. niem. Anatomische Tabellen) ${ }^{13}$.

Z przedstawionej powyżej historii medycyny widać, że w przededniu nadejścia wieku XIX owa nauka rozwijała się dość dynamicznie, korzystała z wielkiego dorobku poprzedników. Przytoczone tutaj nazwiska są pewnego rodzaju znakami czasów - tacy ludzie jak Wesaliusz, Harvey, Morgagni, Leeuwenhoek czy Oczko prowadząc empiryczne badania, pozwolili swoim następcom na dalsze pogłębianie wiedzy medycznej, a co za tym idzie umożliwili dokonywanie nowych odkryć właśnie w przełomowym dla historii medycyny i świata wieku XIX.

Niestety nie jest to miejsce na omawianie dokonań jakże wielu postaci, które przyczyniły się do wzrostu wiedzy medycznej czy też do wypędzania wszelkich zabobonów i introdukcji nowoczesnych działań lekarskich. Wiele czasu zajęłoby też omawianie tematyki farmaceutycznej i ziołolecznictwa. Nie starczyłoby też miejsca na wskazanie jaką rolę w medycynie pełnił przez długi czas zabobon.

Wracając jednak do postaci Leopolda Lafontaine’a, ów krótki, lecz niezwykle obrazowy biogram pokazuje postać człowieka, który pomimo obcego pochodzenia osiadł i prowadził swoją karierę na ziemiach polskich. Podążając przykładem Edwarda Jennera dokonywał popularyzacji szczepienia przeciwko ospie, chociaż sławę przyniosła mu dopiero operacja katarakty ${ }^{14}$ u kobiety niewidomej od urodzenia ${ }^{15}$.

Jednak nie na jego karierze chcę się skupiać, lecz na jego dziele, które wydawał w latach 1801-1802, czyli na „Dzienniku Zdrowia dla Wszystkich Stanów". Było to pismo redagowane przez Lafontaine’a, drukowane jako miesięcznik w Warszawie. Przez historyków zostało ono uznane za pierwsze czysto polskie czasopismo medyczne ${ }^{16}$. Finalnie wyszło jedynie

11 Z. Domosławski, dz. cyt., s. 68.

12 A. Szarewski i in., Joachim Oelhaf and the first public autopsy in Gdansk in 1613, „Folia Morphologica" 2013, vol. 72, no. 4, s. 282.

${ }^{13}$ Historia Gdańskiego Uniwersytetu Medycznego pod adresem https://gumed.edu.pl/ 294.html (dostęp: 14.04.2020).

${ }^{14}$ Dawniej kataraktą nazywano chorobę, którą współcześnie określa się jako zaćmę. Zob. katarakta, [w:] S. Orgelbranda Encyklopedia Powszechna, t. VIII, Warszawa 1900, s. 186-187.

15 T. Ostrowska, dz. cyt.

16 Taż, Historia czasopiśmiennictwa medycznego i jego udział w rozwoju towarzystw naukowych i nauk medycznych w Polsce, „Kwartalnik Historii Prasy Polskiej” 1989, nr 28/4, s. 13. 
12 numerów. Wszystkie zostały napisane w języku polskim, dość przystępnie, z domieszką specjalistycznych nazw łacińskich. Wyszły w sumie 4 tomy, każdy z nich zawierał 3 numery. Odbiorcami pisma byli przedstawiciele „Wszystkich stanów”, albo jak pisze sam autor: „[...] mój Dziennik Zdrowia łaskawej ofiaruję Publiczności"17. Celem Lafontaine’a było m.in. upowszechnienie zasad higieny, uświadomienie i oświecenie ludności, wyzbycie się zabobonu, a także zwrócenie uwagi na problem chorych dzieci. „Dziennik...” rozchodził się drogą prenumeraty (w Warszawie za 27 złp za pół roku, a na prowincji $32 \mathrm{złp).} \mathrm{Cena} \mathrm{pojedynczego} \mathrm{numeru} \mathrm{wynosiła} 6 \mathrm{złp}^{18}$.

Podstawową rzeczą na jaką trzeba zwrócić uwagę przy badaniu „Dziennika..." jest wstęp do pierwszego numeru. Lafontaine już w Przedmowie wykłada wprost o czym będzie jego praca:

Każdy numer tego Dziennika [...] zamykać w sobie będzie rozmaite z nauki lekarskiej czerpane materyje, a nade wszystko opisanie najpospolitszych w życiu ludzkim, a naszemu klimatowi, i sposobowi życia szczególniej właściwych chorób, jak np: kołtuna, hemorrhoidów etc. etc. [...] Greckie i łacińskie słowa, które w Polskim języku znajdują właściwe sobie wyrazy, równie jako i wszystkie lekarstw przepisy, w czystej krajowej mowie układane będą [...] We Francyi i Anglii już przeszło od 20 lat zakazano lekarzom pisać recepty w żadnym innym jak tylko krajowym języku ${ }^{19}$.

A zatem już na wstępie łatwo można zauważyć, że Lafontaine nie będzie zajmować się przypadłościami dla medycyny skomplikowanymi, lecz prostymi, które są problematyczne, ale rozwiązywalne jak np. kołtun. Zawarta też jest informacja dotycząca tego, że wszelkie słowa greckie i łacińskie, które mają odpowiednik w języku polskim będą w „krajowej mowie”. Jest to świetny pomysł, bowiem autor zdaje sobie sprawę, że niewiele osób, do których celuje może owe języki znać. Dodatkowym elementem, ot szczegółem dla badacza historii medycyny jest fakt, że ów lekarz podaje komunikat, że już na Zachodzie tj. w Anglii i Francji nie używa się języka łacińskiego przy wypisywaniu recept, zatem język łaciński został zarzucony na rzecz języków narodowych.

Bardzo ciekawy i warty zauważenia jest fakt, że Lafontaine zwraca się także do księży, którzy są wyrażeni jako „tłumacze wyroków Najwyższego”. Ma dla nich konkretną ofertę. Jaką? Doktor pisze wprost:

17 L. Lafontaine, „Dziennik Zdrowia dla Wszystkich Stanów” 1801, nr 1, s. 3.

18 Dział Informacji, „Dziennik Zdrowia dla Wszystkich Stanów” - pierwsze polskie czasopismo lekarskie, „Ossolineum.pl”, 06.04.2020, www.ossolineum.pl (dostęp: 23.04.2020).

${ }^{19}$ L. Lafontaine, dz. cyt., s. 3. 
Wam także tłumacze wyroków Najwyższego, pomocą w waszym powołaniu podaję rękę. [...] Wy to najpierwsi po wsiach jesteście, u których biedni w swoich potrzebach szukają pomocy. [...] Nie trudno wam będzie w tym obfitym źródle czerpać pożyteczne rady, i te innym w potrzebie udzielać. Wieśniak, który czytać nie umie, i zawsze całodzienną około roli jest zatrudniony pracą, na całą wszą zasługuje uwagę. Nie zapominajcie nigdy, że jesteście Pasterzami powierzonej wam trzody, że ta klasa na wyżywienie nas wszystkich krwawym zalewa się potem, i że wszystkich względów godna jest waszego starania i pieczołowitości ${ }^{20}$.

Jak zatem widać, doktor Lafontaine składa propozycję tego, aby kapłani, będący przecież w prawie każdej wsi jako osoby potrafiące czytać i pisać, udzielali rad lekarskich, o których przeczytają w „Dzienniku...”. Pomysł wydaje się rewolucyjny, wszakże stanowi to pewnego rodzaju ideę powszechnej opieki zdrowotnej tam, gdzie brakuje lekarzy. Już Przedmowa daje pewne wskazówki, które pozwalają dojść do klarownego wniosku - Lafontaine pisał jako prawdziwy oświeceniowiec, chociażby tutaj, kończąc początek wstępu do swojej pracy:

Te są ostatnie moje życzenia: aby z nowo zaczętym wiekiem, oświecenie w nauce lekarskiej, coraz większy wzrost brało, aby każdy mego Dziennika Czytelnik zaczął być postrzegaczem i lekarzem siebie samego; aby zdrowie to najpierwsze i najdroższe $\mathrm{w}$ życiu ludzkim dobro, zawsze w kwitnącym znajdowało się stanie choćby przez to wszyscy Lekarze bankrutami zostać musieli ${ }^{21}$.

Schorzenia trapiące ludzkie zdrowie są różne, jedne bardziej wyniszczające organizm, inne z kolei mniej niebezpieczne. Jedną z chorób, nad którą zdaje się, że ludzkość zwyciężyła, jest gruźlica, od której chcę zacząć. Wydaje się, że zwyciężyliśmy z suchotami (termin wprowadzony przez Hipokratesa jeszcze w okresie Grecji klasycznej, ze względu na niezwykle „wysuszający” przebieg ${ }^{22}$ ), bo rzadko spotykamy je współcześnie w świecie Zachodnim, częściej w krajach Trzeciego Świata. Jednak na początku XIX wieku gruźlica spędzała sen z powiek w zasadzie wszystkim.

Wracając jednak bezpośrednio do „Dziennika...”, należałoby zapytać jak w owym czasie definiowano suchoty, jakie dawały objawy, jakie były czynniki sprzyjające ich rozwojowi, a także jak się przed nimi chronić, o ile jest to w ogóle możliwe. Jak pisze Lafontaine:

20 Tamże, s. 5.

${ }^{21}$ Tamże, s. 8.

${ }^{22}$ E. Dzięciołowska-Baran, A. Gawlikowska-Sroka, Gruźlica-niekończqca się opowieść, „Roczniki Pomorskiej Akademii Medycznej w Szczecinie” 2013, nr 59 (2), s. 158. 
Suchoty, jest to miejscowa choroba w płucach (kiedy ich główna część przez wrzód lub guz jaki bywa naruszona) z wyniszczeniem całego ciała, i tajemną połączona febrą. Ta choroba częstokroć przez wiele lat jak węgiel pod popiołem tleje, czasem zaś prędko się wzmaga, a w tym przypadku Anglicy nazywają tę chorobę galopującymi suchotami ${ }^{23}$.

Dalej zaś kontynuuje, wymieniając konkretne objawy:

Najzwyczajniejsze poprzednicze znaki suchot są kaszel z krwawym zaropiałym odrzutem, albo bez niego; nudność, ciężki oddech, przykrości pochodzące z leżenia na jednym lub drugim boku, kolące w piersiach bóle; chrypka, i sił ubywanie. Za wzmożeniem się coraz większym choroby, następuje najczęściej po południu zimny dreszcz, w czasie zaś snu nocnego gorącość, do której często się dyarya [biegunka - przyp. aut.] jeszcze bardziej siły odejmująca. Jeżeli już do tego przyszło, nogi puchną, uryna rzadka, oddech dla skupiających się w piersiach wodnistych wilgoci coraz staje się trudniejszym, kaszel krwawy się wzmaga, reszta tchu ginie, nareszcie nagłą śmiercią wszystko się kończy ${ }^{24}$.

Jak widać gruźlica miała makabryczny wręcz przebieg i ciężko sobie wyobrazić cierpienia jakie musiał znosić człowiek, który na nią zachorował. Oczywiście każdy kojarzy suchoty z krwistym kaszlem, jednak opis Lafontaine'a jest kierowany bardziej w stronę pewnego makabryzmu działającego na prostą świadomość, inaczej niż bardziej profesjonalny opis według Caeliusa Aurelianusa z V w.:

Pacjenci cierpią na gorączkę utajoną, która zaczyna się pod wieczór i znika ponownie na świcie. Towarzyszy temu gwałtowny kaszel z wydzielaniem rozrzedzonej, ropnej plwociny. Pacjent mówi ochrypłym głosem, oddycha z trudem i ma hektyczne wypieki na twarzy. Skóra reszty ciała jest popielata. Oczy mają zmęczony wyraz, pacjent jest wychudzony w wyglądzie, ale często okazuje zadziwiającą aktywność fizyczną lub psychiczną. W wielu przypadkach słychać charczenie w klatce piersiowej, a kiedy się rozprzestrzenia, pacjent mocno się poci. Pacjenci tracą apetyt i cierpią głód. Są też często bardzo spragnieni. Końce ich palców puchną i paznokcie krzywią się znacznie ${ }^{25}$.

Nie może ulec jednak żadnej wątpliwości fakt, iż gruźlica przedstawiana w taki czy inny sposób, mniej czy bardziej obrazowo, istniała w świadomości społecznej nieprzerwanie, spędzając sen z powiek tym, którzy przez przypadek znaleźli się w okolicy, gdzie stwierdzono jej występowanie. Odbierała życie wszystkim, bez względu na wiek, pochodzenie społeczne.

${ }^{23}$ L. Lafontaine, O przyczynach tak często po wielkich miastach panujących suchot i o środkach ich uniknienia, „Dziennik Zdrowia dla Wszystkich Stanów” 1801, nr 2, s. 153.

${ }^{24}$ Tamże, s. 153-154.

${ }^{25}$ E. Dzięciołowska-Baran, A. Gawlikowska Sroka, dz. cyt., s. 158. 
Gdzie zatem Lafontaine upatruje podstawowych problemów powstawania gruźlicy? Na piedestale stawia sprawę urbanistyki i budowy ciała. Lekarz stwierdza, że mieszkańcy większych miast na ogół są bardziej podatni na choroby, ze względu na słabsze ciała o delikatniejszej budowie, inaczej niż ma to miejsce w przypadku wieśniaków. Idąc dalej tym tropem, dzieci z rodzin, które mieszkają w wielkich miastach, mogą dziedziczyć po rodzicach nie tylko wiele chorób, między innymi te „które są wstępem do suchot”26.

Wszelkich czynników ryzyka według Lafontaine’a powinni przestrzegać ludzie, którzy mają delikatne ciało, skórę bladą i cienką, białe zęby, płaskie piersi i wystające łopatki. Tuberkuloza, bo tak też można nazywać gruźlicę, dotyka osoby, które wytracają ciepło, pomimo powszechnego przekonania, że chłód jest czynnikiem wzmacniającym. Zakazane też są przejażdżki saniami lub konno po zimnie. Dieta - wskazana tylko wzmacniająca, nie ascetyczna - powinna składać się z mięsa, jaj oraz mleka, a także wina - po łyżce na dzień, jeśli ktoś nie jest przyzwyczajony ${ }^{27}$.

W osobnym podrozdziale „Budowa, odległość mieszkań, i inne wielkim miastom właściwe niewygody" Lafontaine zdecydowanie bardziej rozwija temat budownictwa. Już zdanie otwierające ów fragment zawiera wiele mądrości ówczesnych, a wykazuje nieświadomość ascendentów:

Po znacznej liczbie wielkich miast widzieć można, że początkowo nie na to były założone, czym są teraz. Można nawet o wielu z nich twierdzić, że samo ich geograficzne położenie jest początkiem rozlicznych, a mianowicie piersiowych chorób. Warszawa w swoim położeniu tak jest władzy rozmaitych wystawiona wiatrów, i tylu powietrza podlega odmianom, że często w jednym dniu wszystkie niewygody z przemiany czterech części roku wytrzymać musi ${ }^{28}$.

Absurdem oczywiście byłoby oskarżanie założycieli miast, że nie dostosowali ich do potrzeb przyszłych mieszkańców. Lafontaine zauważa, że wpływ na choroby, między innymi na wspomnianą wyżej tuberkulozę, ma położenie miejscowości. Nie jest to wniosek nowy, bowiem już rzymski architekt Witruwiusz w I w. p.n.e. w swoim dziele De architectura libri decem wskazywał na to, że miasta należy budować podług określonego porządku z różnych względów (unikając np. oparów bagiennych albo bryzy) ${ }^{29}$. Jednak pewne zapomnienie sztuki urbanistycznej spowodowało, że układy budowanych miast pozostawały przez długi czas różne, a zmiany przyniosła dopiero II poł. XIX w.

\footnotetext{
${ }^{26}$ L. Lafontaine, dz. cyt., s. 155-156.

27 Tamże, s. 157-159.

${ }^{28}$ Tamże, s. 162-163.

${ }^{29}$ Zob. Witruwiusz, $O$ architekturze 10 ksiag, tłum. K. Kumaniecki, Warszawa 2004, s. 33-44.
} 
Na wysokości budynków szczególną uwagę zwraca usilnie Lafontaine. Jak czytamy:

Domy wielkich miast składają się z mieszkań dolnych, oraz z pierwszego, drugiego i trzeciego piętra; w pierwszych najwięcej ludzi suchotom podlega. Mieszkańcy dolni w prawdziwych żyją piwnicach, do których prawie nigdy nie dochodzi słońce. [...] Niedostatek światła może tylko ciało osłabić i do chorób usposobić, lecz złe i nieczyste powietrze, które jest naturalnych takowych mieszkań skutkiem, bywa przyczyną suchot. [...] Nie dziw zatem, iż niskie mieszkania, jeżeli nie same suchoty, jednakże przynajmniej do nich dają usposobienie ${ }^{30}$.

Inaczej jednak przedstawia się sprawa mieszkań na wyższym piętrze, chociaż nie do końca można tutaj mówić wyłącznie o plusach, ponieważ istnieją także minusy takiego stanu rzeczy. Oczywiście - im wyżej, tym powietrze lepsze i dostęp do promieni słonecznych również. Problem zasadza się w kwestii schodów prowadzących do pokoi. Zbyt szybkie i zbyt częste wchodzenie i schodzenie po nich, może być przyczyną suchot. Niestety - biedni słudzy, aby zarobić na utrzymanie swoje i swoich rodzin biegać po nich muszą, nosić drwa i pakunki. Innymi słowy - zdrowie przehandlowane na pieniądze z powodu konieczności.

Jak powszechnie wiadomo - lepiej zapobiegać niż leczyć. Jak jednak i czy w ogóle można w jakikolwiek sposób chronić się przed zarażeniem się gruźlicą? Czy na początku XIX wieku istniał sposób na to, aby uleczyć się z tej potwornej choroby?

Tutaj ponownie Lafontaine porusza sprawy urbanistyki. Nie jest sposobem na rozwiązanie problemu budowanie niższych domostw z prostej przyczyny - ludzie zaczną mieszkać na tym samym poziomie, lecz obok siebie. Zniesienie wysokich budynków, chociażby według najlepszych intencji jakie można sobie wyobrazić, w opinii lekarza wcale nie zapobiegnie suchotom ${ }^{31}$.

Zmorą XIX wieku, wydawać by się mogło, jak nigdy wcześniej był kurz i pył. Dawało się to we znaki zwłaszcza ludziom, którzy pracowali w takich zawodach, które wymagały kontaktu z owymi lotnymi cząstkami. Na suchoty narażeni byli m.in. młynarze, kamieniarze, mularze, kominiarze oraz zapominani... perukarze. Niektóre zawody są konieczne dla funkcjonowania tkanki społecznej, bo bez pracy młynarza nie ma mąki, a z niej chleba - podstawowego produktu spożywczego wszystkich stanów. Z drugiej strony jednak można obejść się bez perukarzy i czesać się samemu. Lafontaine nie mówi tego wprost, lecz wyczuwa się w jego wypowiedzi ton silnej niechęci wobec

\footnotetext{
${ }^{30}$ L. Lafontaine, $d z$. cyt., 1801, nr 2, s. 163-165.

31 Tamże, s. 166.
} 
tych, których zawody do funkcjonowania społeczeństwa nie są konieczne, ale istnieją i narażają się na silne ryzyko zachorowania na gruźlicę ${ }^{32}$. $\mathrm{Z}$ trzeciej jednak strony pozostaje silne wrażenie, że doktor Lafontaine myli suchoty z pylicą, chociaż nie przywołuje przykładu żadnego górnika, z którym to schorzenie jest kojarzone.

W pewnym stopniu Dziennik... przybiera z lekka moralizatorski ton, który widać już pod koniec omawianego rozdziału. Lafontaine nawołuje do wszelkiego pomiarkowania w różnych codziennych zabawach, ponieważ wierzy, że przesada prowadzi do wzmiankowanej choroby. Bardzo obrazowe, względem osób grających na instrumentach dętych, jest jedno ze zdań zawarte już pod koniec rozdziału, a mianowicie:

Waltornia, fagot, klarnet, fletrowers, nie są w tym względzie dla nikogo obojętnymi. [...] Kto zatem do suchot jest skłonnym, i przez nie jak najprędzej wyniszczonym być pragnie, pewno przez te instrumenta resztę swojego życia wydmucha ${ }^{33}$.

Co jednak powiedzieć można o leczeniu i zapobieganiu? Najprościej ujmując sprawę - należy unikać pyłów a wszystko co robić, czynić z umiarem i wstrzemięźliwością. Czasem też domniemane suchoty były po prostu zwykłym kaszlem albo pylicą. Praktyka lekarska mówi jasno - w owym czasie możliwe było wyłącznie leczenie w uzdrowiskach.

Co mówi jednak praktyka ludowa? Współcześnie może się to wydawać dość zaskakujące, ale tam, gdzie nie sięgały porady lekarskie, na gruźlicę używano psiego sadła, które mieszano z wódką, piwem lub mlekiem albo części ciała różnych zwierząt - od świeżo zarżniętego cielęcia zabierano płuca i serce, siekano i dodawano do jakiegoś płynu, który podawało się choremu. Poza tym lekarstwa na tuberkulozę upatrywano w gotowanej owczej skórze ${ }^{34}$.

Choroba ta trawiła ludzkość przez ponad jeszcze sto lat. Przełomowe odkrycie Roberta Kocha z 1882 r. wskazujące na prątek gruźlicy jako czynnik chorobotwórczy przyczyniło się do opracowania skutecznej szczepionki dopiero w 1924 r. przez Alberta Calmette'a i Camille'a Guerina ${ }^{35}$.

Innym zagadnieniem, które Lafontaine porusza w obszernych jakby nie patrzeć „Dziennikach...” jest sprawa kołtuna, który zwano również plica polonica, gwoździec lub goździec, Trichoma, Trierae incubor, Morbus Cirrorum,

32 Tamże, s. 169.

33 Tamże, s. 171.

${ }^{34}$ D. Sztych, Zastosowanie odzwierzęcych środków leczniczych w medycynie ludowej, „Wiadomości Zootechniczne" 2018, R. 61, nr 2, s. 147, 152.

35 E. Dzięciołowska-Baran, A. Gawlikowska-Sroka, Gruźlica ..., s. 159. 
Capilnium intricotum u Niemców zaś Wichtelzopf ${ }^{36}$. Choroba ta pierwszy raz jest wzmiankowana w jednym z czeskich rękopisów z 1325 r., na ziemiach polskich wspomina o niej w 1599 r. kanclerz Jan Zamoyski ${ }^{37}$. Współcześnie kołtun uchodzi za rzecz niebywałą - symbol brudu i zaniedbania.

Gdybyśmy zadali doktorowi Lafontaine'owi pytanie czym jest kołtun, dostalibyśmy następującą odpowiedź:

Kołtun Trichoma, (plica polonica) jest w Polszcze i pogranicznych krajach domową chorobą, w której jej materia kołtunowa w czasie zburzenia (crisis) osiada we włosach i tak je skleje, że ich ani sztuką, ani pilnością, rozwikłać i wyczesać nie można. Ta materyja nie tylko przechodzi we włosy, ale też osiada na paznokciach rąk i nóg, szczególniej u tych, którym zbywa na włosach, albo ze wszystkim są ucięte. Czasem to krytyczne osiadanie następuje na paznokciach obu rąk i nóg, które robią się większe, grubsze, niegładkie, nieforemne, brzydkiego koloru i rogowate, ale nie czarne. Często się wydarza, że osiada razem we włosach i paznokciach ${ }^{38}$.

Wyżej umieszczony opis przekazuje już na wstępie bardzo istotne informacje - między innymi to, że kołtun jest chorobą występującą w Polsce i w krajach pogranicznych (blisko granicy), co jest zgodne z prawdą w pewnym stopniu, bowiem taki pogląd potwierdza współczesny Lafontaine’owi lekarz Thomas Emmanuel Chromy, który wspominał: „Choroba ta własna krajom Tartaryi, Rusi, Polski i innym aż do początku Wisły [...] na południe i zachód rozszerzająca się"39. Lafontaine jednak dopiero nieco dalej wspomina o innych terenach, gdzie takie schorzenie występuje, czyli o Szwajcarii, Alzacji, Bryzgowii i Francji ${ }^{40}$.

Zaczytując się $\mathrm{w}$ dalsze stronnice pracy doktora, spotykamy wysyp różnych objawów i przyczyn, które świadczą o istnieniu kołtuna. Do najpowszechniejszych z symptomów, które dzielą się na łagodne, bolesne i gwałtowne należą: bóle reumatyczne przenoszące się po całym ciele, paraliż, odrętwienie, zapalenie w płucach, dyzenteria, melancholia (depresja). Owa choroba może również objawiać się w określonych narządach - jeżeli w oczach, następują zapalenia, czarna i szara katarakta; jeśli na członkach to pojawiają się guzy, nabrzmiałość, wrzody i gangrena; jeżeli przejdzie do

${ }^{36}$ T.E. Chromy, Naynowsze dostrzeżenia nad chorobq kołtona: za dodatek do historii iego natury własności i szrodkow leczenia służące w okolicy Krakowa i części Galicyi Zachodniey zebrane, Warszawa 1809, s. 9.

37 A. Völker, A. Skobacki, Lekarz olsztyński Joachim Kornalewski i jego rozprawa o kołtunie z 1897 r., „Kontakty Mazursko-Warmińskie” 1980, nr 2, s. 157.

38 L. Lafontaine, O kołtunie, „Dziennik Zdrowia dla Wszystkich Stanów” 1801, nr 6, s. 335.

39 T.E. Chromy, dz. cyt., s. 10.

${ }^{40}$ L. Lafontaine, dz. cyt., 1801, nr 6, s. 335. 
szpiku kostnego to staje się wtedy przypadłością nieuleczalną. Inne symptomy to również ból w krzyżu, dychawica (astma), szum w uszach, niepochamowana skłonność do wódki, u kobiet zaś ustaje miesiączka ${ }^{41}$. Chociaż i tak najważniejszym objawem jest to, co powstaje z włosów na głowie.

Podobne objawy, potwierdzające słowa Lafontaine'a, widnieją u Chromy'ego:

Przypadłości, które, które chorobę kołtónową, poprzedzać zwykły [...] spostrzegłem następujące, to jest: rozmaity ból głowy, zawrót głowy, zbyteczną lub też zupełnie przytłumioną czułość skóry na głowie [...] dzwonienie, kłucie w uszach, słaby słuch i pieczenie w uszach [...] słabość wzroku, naciskanie, palenie, łzawienie się lub ropienie i czerwoność oczów [...] rozmaite bole twarzy, gwałtowne na twarzy rozpalania się, ckliwości, a pod czas naciskanie w dołku, pod czas kurcz żołądkowy z forsownemi wymiotami [...] często gwałtowne zrywanie całego ciała [...] bóle reumatyczne lub artrytyczne [...] i wykręcania całego ciała są to prawdziwe cechujące tę chorobę przypadłości ${ }^{42}$.

W świadomości społecznej wobec kołtuna zdania były podzielone. Liberalne środowiska medyczne uważały go za chorobę i symbol brudu, konserwatywni lekarze dystansowali się od tak radykalnego zdania. Mieszkańcy wsi, których ta choroba dotyczyła w największym stopniu, po pomoc lekarską zwracali się w ostateczności, a w pierwszej chwili kontaktowano się z lokalnymi zielarzami lub starcami, na doświadczeniu których się opierano. Stąd też medycyna ludowa uważała, że kołtun nie jest wynikiem braku higieny, lecz sprawą magiczną, urokiem, który należało odczynić poprzez określone obrzędy, do których należało na przykład wypicie mikstury złożonej z wódki i bocianiego sadła albo upalenie z woskiem krwi jaszczurki ${ }^{43}$.

Wracając do Dziennika ... doktor Lafontaine uznaje, że przyczyną powstania kołtuna jest jakaś dziwna materia, wobec której nie wyraża się dość jasno i lawiruje między tym, że jej proweniencja wiąże się albo z chorobą weneryczną, szkorbutową, Scrophulosa albo ze stawami albo jeszcze i z limfą ${ }^{44}$.

Kołtun dotyka każdego, bez względu na pochodzenie społeczne, zajęcie czy też płeć. Jednak jego rozwój i wygląd różnił się u kobiet i mężczyzn, także sama jego klasyfikacja jest dość zróżnicowana, bo typy kołtuna Lafontaine segreguje w 3 grupy. W przypadku pierwszej mamy do czynienia z prawdziwym, fałszywym, prawdziwym i fałszywym zarazem; w przypadku drugiej z łagodniejszym albo bardzo złym; trzecia grupa zawiera w sobie kołtuny pojedyncze, wielorakie albo odchodzący od głowy ${ }^{45}$.

\footnotetext{
${ }^{41}$ Tamże, s. 339-341.

42 T.E. Chromy, dz. cyt., s. 23-24.

43 D. Sztych, dz. cyt., s. 148, 149.

${ }^{44}$ L. Lafontaine, dz. cyt., 1801, nr 6, s. 350.

45 Tamże, s. 343, 346.
} 
Co w takim razie ze sposobami leczenia tej przypadłości? W końcu zapach tego wytworu włosowego wcale nie jest przyjemny, a wręcz przeciwnie. Przede wszystkim sposób kuracji powinien być dobrany do czasu, w jakim kołtun się tworzył. Na początku choroby, zanim wejdzie ona jeszcze we włosy, ale kleista maź już się pojawi, doktor rekomenduje używanie ziół np. Bardana (łopian), Radix graminis (perz), Cikoria, Taraxacum (lwi ząb) czy Fumaria (dymnica); połączyć z nimi warto inne takie jak Extractum Aconiti (ekstrakt z tojadu) czy Cicutae (szalej). Jeśli trwa akurat lato, należy stosować soki zielone $\mathrm{z}$ bulionem lub serwatką. $\mathrm{W}$ przypadku momentu przed przejściem mazi we włosy, stosować się powinno m.in. proszek Dowera czy Aconitum z kamforą. Powyższe metody należy wykorzystywać tylko wtedy, kiedy nie ma febry. Lecz jeśli i ona zaistnieje, potrzeba dokonać upuszczenia krwi z zachowaniem wszelkiej ostrożności ${ }^{46}$.

Pikanterii całej sprawie nadaje fakt dychotomii między tym czy kołtuna obcinać czy też nie i dlaczego. Podstawą do pozbycia się tego zlepku włosów jest wybranie odpowiedniej pory. Najlepszym momentem do ścinania jest moment, kiedy kołtun wyschnie i znikną jego wszystkie symptomy, lecz nie można usuwać od razu całego. Należy ścinać codziennie rano tylko same wierzchnie jego końce. Jeżeli kołtun jest jednak stary, można pozbyć się całego od razu, nowe włosy natomiast należy umyć i wyczesać. Ucinanie go jednak jest zakazane w momencie, gdy jest nowy, siedzi na głowie, wydaje zły zapach i nie ustały wszystkie symptomy. Jeśli jednak ucięcie go nastąpiło wcześnie i pojawiają się objawy niebezpieczne dla zdrowia należy przywrócić go na jego dawne miejsce. W przypadku kiedy odcięty kołtun nie chce się trzymać, należy przecierpieć swoje ${ }^{47}$.

Owa choroba jest niezwykle dziwna. Niektórzy stwierdzali, że jest dziedziczna, inni że zaraźliwa. Przed „Dziennikiem...” powstało co najmniej 230 prac na jego temat, począwszy od czternastowiecznego czeskiego rękopisu $^{48}$. Na gruncie polskim ostatecznie z ową chorobą rozprawił się Henryk Dobrzycki w wydanej w 1877 r. pracy $O$ kołtunie pospolicie "plica polonica” zwanym. Jednak zabobon ciężko było wykorzenić, czego wyrazem jest fakt, że ostatni zanotowany przypadek kołtuna został opisany w 1963 r. przez Zbigniewa Woźniewskiego ${ }^{49}$.

Jako ostatnie schorzenia, które pragnę opisać, a o których pisał Lafontaine w „Dziennikach...” są choroby zębów. Autor wspomina różne problemy

${ }^{46}$ L. Lafontaine, dz. cyt., 1801, nr 7, s. 40-42.

47 Tamże, s. 49-51.

48 Zob. H. Dobrzycki, O kołtunie pospolicie „plica polonica” zwanym, Warszawa 1877, s. 251-262.

${ }^{49}$ A. Völker, A. Skobacki, dz. cyt., s. 158. 
z nimi związane a są to np.: katarowy ból zębów oraz tępość, nieco dalej wymienia jeszcze bardzo ciekawe sposoby na wypełnienie pustego zęba, a także to jak unikać i pozbywać się kamienia.

Tym razem zacznę od problemu pustego zęba. Czy należy go wyrwać, czy może jednak spróbować przeprowadzić jakiś zabieg, który wypełni pustą przestrzeń? Odpowiedź Lafontaine’a na to pytanie jest następująca:

Kiedy ząb jest pusty, i już znaczną otrzymał jamę, można często zapobiedz jego bólowi, napełniając tę jamę czymkolwiek, np. woskiem, mastyksem, ołowiem, cyną, złotem, i tamując przez to wnijście powietrza, pokarmów i napojów. Jeżeli dno tej jamy jest ciasne, a otwór zewnątrz obszerny, więc mięknie rzeczy jako wosk, najlepiej służą, ta tylko jest z tym połączona niedogodność, że skoro przy żuciu wypadną, za każdym razem na nowo wkładane być muszą. Przeciwnie kiedy zewnętrzny otwór jest ciasny, i dno obszerne, wyż wspomnione metale zasługują na pierwszeństwo ${ }^{50}$.

Jedynie oczami wyobraźni możemy zobrazować sobie jak bolesne musiało być uzupełnianie pustej przestrzeni zębowej przy pomocy metali (złoto, cyna, ołów) czy też innych substancji takich jak żywica z drzewa pistacji (mastyks). Oczywiście zanim dokonano takiego zabiegu wypełnienia, należało znieczulić miejsce, do którego substancja będzie wlewana. Doktor Lafontaine sugeruje, aby użyć do tego nieco bawełny, którą do pustej przestrzeni należy włożyć, a która wcześniej powinna być „odwilżona” w olejku z kajaputu, cynamonu, goździków i tymianku albo w rozrzedzonych kwasach mineralnych. Nie zaszkodzi także użyć nieco opium, które należy przyłożyć do zęba. W ostateczności trzeba wypalić nerw, wtedy ból z pewnością minie ${ }^{51}$.

Tępość zębów wg Lafontaine’a to skutek „wykroczenia” w diecie, a także spożywania zbyt dużej ilości młodego wina oraz złej strawności. Największym problemem były sprawy żołądkowe, bowiem od nich miał się brać problem powstawania kwasu w ciele, który miał wchodzić w krew i przyczyniać się do kiepskiego stanu uzębienia. Na taką przypadłość, Lafontaine zalecał gorzkie lekarstwa wzmacniające żołądek, a bezpośrednio na zęby powinno się używać suszonej skórki chlebowej $\mathrm{z}$ popiołem $\mathrm{z}$ tytoniu ${ }^{52}$. Mądrość ludowa z kolei sugerowała użycie sadła zajęczego ${ }^{53}$.

${ }^{50}$ L. Lafontaine, O zębach, „Dziennik Zdrowia dla Wszystkich Stanów” 1802, nr 9, s. 298-299.

51 Tamże.

52 Tamże.

53 D. Sztych, dz. cyt., s. 152. 
Wyrywanie zębów z kolei jest uzasadnione w określonych przypadkach:

[...] jeżeli jaki ząb nie tylko zupełnie jest zepsuty, ale też poboczne zaraża, jeżeli ząb przez swoją zgniłość i pochodzący stąd fetor, nie tylko samemu choremu, ale też innym osobom sprawuje przykrość, jeżeli się chwieje i wcale umocowanym być nie może, tak, że przez częste dotykanie języka i pokarmów ból przynosi, więc wyrwanym być musi ${ }^{54}$.

Jak więc widać warunki wyrwania zęba są jasno określone. Jednym z najważniejszych kryteriów ku pozbyciu się go jest ból; jeżeli sprawuje przykrość innym osobom (zepsute zęby mają bardzo niemiły zapach) oraz jeżeli się chwieje też musi zostać wyrwany. Gdyby po wyrwaniu, krwotok nie ustawał, należy trzymać w ustach mocną wódkę, spirytus witriolu lub kawałek hałunu ${ }^{55}$. Podobne uwagi względem wskazań do pozbycia się zęba czyni w swojej pracy Jan Anns (co prawda w dziele z 1849), rozszerzając je na inne przypadki, a także wskazując, kiedy zęby nie mogą być usunięte ${ }^{56}$.

Ostatnim aspektem, który pragnę poruszyć jest sprawa kamienia nazębnego, który pojawia się w pracy Lafontaine’a. Zwracając uwagę na to zagadnienie, doktor podkreśla już z początku jak dbać o higienę uzębienia:

Nade wszystko trzeba starać się o zapobieżenie wzmagającym się nieczystościom i osadowi kamienia na zębach. Najlepiej się to dzieje przez pilne płukanie ust zimną wodą i przez nacieranie ich chustą. Czynić to należy, tak w poranku wstawszy; jak po każdym jedzeniu i w wieczór, przed udaniem się do wczasu $^{57}$.

Takie zalecenia były aktualne jeszcze w 50 lat po wydaniu „Dziennika...” ponieważ w podobnym tonie wypowiada się Jan Anns ${ }^{58}$. Ponadto później Lafontaine wspomina także, że bardzo ważną rzeczą jest, aby pilnować zwłaszcza dzieci przy myciu zębów, lecz zwracać uwagę trzeba też na to, aby szczoteczkami nie zetrzeć emalii. Lekarz nawołuje także do tego, aby zniechęcać młodzików do grzebania w szparach między zębami, ponieważ przyczynia się to do kruszenia całej ich struktury ${ }^{59}$.

Podsumowując, praca Lafontaine'a zawiera w sobie mnóstwo bezcennych informacji. Korzystać z niej mogą nie tylko badacze historii medycyny,

\footnotetext{
${ }^{54}$ L. Lafontaine, $O$ zębach, 1802, nr 9, s. 300.

55 Tamże.

56 Por. J. Anns, Wykład praktyczny chorób zębów i ich leczenia, Warszawa 1849, s. 32-33.

57 L. Lafontaine, $O$ zębach, 1802, nr 9, s. 300.

58 J. Anns, dz. cyt., s. 27.

${ }^{59}$ L. Lafontaine, $O$ zębach, 1802, nr 9, s. 301-302.
} 
lecz również językoznawcy czy kulturoznawcy. Rozwój terminologii zafascynuje każdego, kto pragnie poznać ówczesną semantykę. Problemy medyczne opisane w „Dzienniku...” są niewątpliwie godne szerszego rozważenia i skomentowania, zwłaszcza przez badaczy historii medycyny. Niniejsza praca miała na celu jedynie odwołać się do określonych problemów, jednak uważam, że Lafontaine zawarł wiele wątków, które powinny być dodatkowo przeanalizowane.

\section{BIBLIOGRAFIA}

\section{Źródła drukowane}

Anns J., Wykład praktyczny chorób zębów i ich leczenia, Warszawa 1849.

Chromy T.E., Naynowsze dostrzeżenia nad chorobq kołtona: za dodatek do historii iego natury własności i szrodkow leczenia służące w okolicy Krakowa i części Galicyi Zachodniey zebrane, Warszawa 1809.

katarakta, [w:] S. Orgelbranda Encyklopedia Powszechna, t. VIII, Warszawa 1900.

Lafontaine L., „Dziennik Zdrowia dla Wszystkich Stanów” 1801, nr 1.

Lafontaine L., „Dziennik Zdrowia dla Wszystkich Stanów” 1801, nr 2.

Lafontaine L., „Dziennik Zdrowia dla Wszystkich Stanów” 1801, nr 6.

Lafontaine L., „Dziennik Zdrowia dla Wszystkich Stanów” 1802, nr 7.

Lafontaine L., „Dziennik Zdrowia dla Wszystkich Stanów” 1802, nr 9.

Witruwiusz, $O$ architekturze 10 ksiag, tłum. K. Kumaniecki, Warszawa 2004.

\section{Opracowania}

Dobrzycki H., O kołtunie pospolicie „plica polonica” zwanym, Warszawa 1877.

Domosławski Z., Wprowadzenie do medycyny, Jelenia Góra 2007.

Dzięciołowska-Baran E., Gawlikowska-Sroka A., Gruźlica - niekończq̨ca się opowieść, „Roczniki Pomorskiej Akademii Medycznej w Szczecinie" 2013, nr 59(2).

Gest H., The discovery of microorganisms by Robert Hooke and Antoni van Leeuwenhoek, fellows of the Royal Society, "Notes and Records of the Royal Society of London” 2004, nr 58(2).

Grzybowski A., Sak J., Józef Struś (1510-1568) jako prekursor współczesnej wiedzy o układzie krążenia w 500. rocznicę jego urodzin, „Archiwum Historii i Filozofii Medycyny” 2011, vol. 74.

Jeszke J., Myśl europejska w medycynie polskiej w XIX w. w badaniach polskich historyków medycyny, „Medycyna Nowożytna” 1996, nr 3/1-2.

Markiewicz M., Historia Polski 1492-1795, Kraków 2011.

Ostrowska T., Franciszek Leopold Lafontaine, [w:] Polski Słownik Biograficzny, t. XVI, Wrocław-Warszawa-Kraków 1971. 
Ostrowska T., Historia czasopiśmiennictwa medycznego i jego udział w rozwoju towarzystw naukowych i nauk medycznych w Polsce, „Kwartalnik Historii Prasy Polskiej” 1989, nr 28/4.

Szarewski A. i in., Joachim Oelhaf and the first public autopsy in Gdansk in 1613, „Folia Morphologica" 2013, vol. 72, no. 4.

Sztych D., Zastosowanie odzwierzęcych środków leczniczych w medycynie ludowej, „Wiadomości Zootechniczne" 2018, R. 61, nr 2.

Völker A., Skobacki A., Lekarz olsztyński Joachim Kornalewski i jego rozprawa o kołtunie z 1897 r., „Kontakty Mazursko-Warmińskie” 1980, nr 2.

Węglorz J., Zdrowie, choroba i lecznictwo w społeczeństwie Rzeczypospolitej XVI-XVIII wieku, Toruń 2015.

\section{Źródła internetowe}

https://gumed.edu.pl/294.html (dostęp: 14.04.2020).

https://ossolineum.pl/index.php/dziennik-zdrowia-dla-wszystkich-stanow-pierwszepolskie-czasopismo-lekarskie/ (dostęp: 23.04.2020).

Szymon Polak

\section{“A JOURNAL OF HEALTH FOR ALL THE ESTATES" BY FRANZ LEOPOLD LAFONTAINE AND THE STANDARD OF MEDICAL KNOWLEDGE IN THE EARLY $19^{\mathrm{TH}}$ CENTURY. SELECTED DISEASES}

\footnotetext{
$\mathrm{T}$ he issue of diseases and attempts to treat them has troubled humanity since the dawn of time. However, with the passage of time, the state of medical knowledge grew, and in the Renaissance there was a real revival of human sciences, which resulted in the works of such people as Andreas Vesalius, William Harvey or Giambattista Morgagni, and in the Commonwealth Wojciech Oczko or Joachim Delhafius. The symbolic work that introduces medicine not only in the nineteenth century, but also into the deep province is the "Health Journal for All States” by Franz Leopold Lafontaine. The analysis of three types of diseases: tuberculosis, smug and dental issues in relation to other researchers allows to compare the state of medical knowledge not only with what occurred before, but also with how these diseases were later looked at.
}

Keywords: health issues, tuberculosis, smug, dental issues, health. 